\title{
Gyốr lakásügyi politikája a rendszerváltás után
}

\section{Housing Policy of Gyốr after the Change of Regime}

\section{ÖsSZEFOGLALÁS}

A tanulmány Gyôr lakásügyi politikáját és azon belül az önkormányzat által ellátott lakásügyi feladatokat kívánja bemutatni 1990tôl napjainkig. Az 1990-es rendszerváltás az újonnan megalakult gyôri önkormányzatot is nagy fokú önállóság és egyúttal óriási feladat elé állította a közszolgáltatások szervezése tekintetében, nem volt ez másként a lakásgazdálkodás területén sem.

Journal of Economic Literature (JEL) kódok: H55, O18, R31, R38

Kulcsszavak: Gyôr humánszolgáltatási modellje, lakásügyi politika, lakásgazdálkodás, helyi közszolgáltatások szervezése

\section{Summary}

In this paper I analyse housing policy in Gyôr and the related functions of the local government from 1990 to date. The 1990 change of regime also resulted in a new local government in Gyôr, a high degree of independence and, at the same time, enormous tasks in the field of public services, and this was also the case in housing management.

Journal of Economic Literature (JEL) codes: H55, O18, R31, R38

Keywords: human services model in Gyôr, housing policy, housing management, provision of local public services

\section{Bevezetés}

Gyôr megyei jogú város általam felvázolt humánszolgáltatási modelljének négy meghatározó eleme van. Az egyik elem a szociálpolitika, az önkormányzat által ellátott kötelezố és önként vállalt feladatok összessége, a helyi szociális ellátórendszer keretén belül. A szociálpolitikai pillérhez szorosan kapcsolódva a modell másik területe a lakásügy, mely többek között kiterjed az önkormányzati tulajdonban lévô lakások hasznosítá-

Laczkovits-TAkÁcs TímEA, doktorjelölt, Széchenyi István Egyetem, Regionális- és Gazdaságtudományi Doktori Iskola (takacs.timea@sze.hu). 


\section{Tudományos múhely}

sára, illetve lakáscélú támogatások biztosítására, mellyel részletesen foglalkozik a tanulmány. A harmadik meghatározó elem az egészségügyi alapellátás körébe tartozó önkormányzati feladatok biztosítása. A helyi egészségügyi ellátórendszerhez kapcsolódva azonosíthatjuk be a negyedik pillért, az Egészséges Városok Program keretében nyújtott szolgáltatásokat, kezdeményezéseket, melyet a győri önkormányzat önként vállalt feladatként lát el.

\section{SZAKIRODALOM ÁTTEKINTÉSE}

Gyôr az elmúlt időszakban számtalan tudományos kutatás középpontjában állt. A humánszolgáltatások gyốri modelljéhez szorosan kapcsolódva többek között a vizsgálatok tárgyát képezte a Gyôrben élők alapvető szükségleteinek feltérképezése, mely vizsgálat tudományos eredményei segítséget nyújthatnak a város humánszolgáltatásokat nyújtó intézményrendszerének a szükségletek felismerésében és új megoldások, válaszok megfogalmazásában (Nárai, 2014a). A humán szükségletek feltérképezése során további kutatások irányultak a magasabb rendú aktivitási szükségletek vizsgálatára is, ahol empirikusan is alátámasztva, hogy egy prosperáló térségben, így Gyôrben is jelen vannak az egyenlőtlenségek, és az alapvetô szükségletek kielégítetlensége gátolja a magasabb szintú szükségleteknek nemcsak a kielégülését, hanem sok esetben a felmerülését, felismerését is (Nárai, 2014b). Mindezek új irányokat, kihívásokat jelentenek a helyi szociális ellátórendszer számára. A gyốri helyi szociális ellátórendszer múködése számos állami, önkormányzati és magánszektorhoz kapcsolódó intézmény, szervezet szoros együttmúködését teszi szükségessé, mely együttmúködések feltérképezésével, beazonosításával több kutatás is foglalkozott az elmúlt idôszakban (Budai, 2014; Budai-Puli, 2014). Ezen gyôri várostérség tágabb vonzáskörzetében tevékenykedô, szociális feladatokat ellátó intézmények belsô, egymás közti, és kifelé, más intézmények felé mutató együttmúködési kapcsolatait elemezte Csizmadia (2014a) is. További, a szociálpolitikához kevésbé szorosan kapcsolódó kutatások is több irányból veszik górcsố alá a helyi, gyôri társadalom egyes szegmenseit. Míg Róbert (2014) a gyôri lakosság társadalmi rétegzôdését és mobilitását vizsgálta, addig Páthy (2014) kutatásai a gyôri városrészek és lakóövezetek társadalmi tagozódását helyezte a vizsgálatok középpontjába, Tóth és Ditrói (2014) pedig a helyi társadalom további dimenzióit elemezte. A gyoóri társadalmat vizsgálta három további kutatás, újabb empirikus eredmények hozzáadásával. A kutatások kitértek a gyôri identitás és háttértényezôinek vizsgálatára (Bugovics, 2014), feltérképezték a kapcsolati tôke bizonyos formáit Gyôr vonatkozásában (Csizmadia, 2014b), valamint átfogó képet nyújtottak a gyooriek társadalmi részvételérôl (Reisinger, 2014a).

A közszolgáltatások területi és szervezeti hatékonyságát és gyôri példákat mutatott be Dusek (2014) egyik kutatása. Gyôr humánszolgáltatási modelljével és azon belül az egészségügyi feladatok ellátásával szintén foglalkozott Laczkovits-Takács (2018a). Külön vizsgálat irányult a gyôri szociálpolitika fejlődési ívére, szerepének vizsgálatára Gyôr stratégiai dokumentumainak tükrében (Laczkovits-Takács, 2019c), valamint a gyôri önkormányzat szerepvállalására a szociális közszolgáltatások biztosításában (Laczkovits-Takács, 2019a). A gyôri humánszolgáltatási modell Egészséges Városok Program pillérje is a tudományos érdeklődés középpontjában állt az elmúlt idôszakban (Laczkovits-Takács, 2018b; Laczkovits-Takács, 2019b; Laczkovits-Takács, 2019d). A gyôri modell lakásügyi pillérjéhez kapcsolódva, annak egy szegmensét vizsgálta egy másik kutatás az újvárosi szociális városrehabilitáció elemzése révén (Fekete-Laczkovits-Takács, 2019a; 2019b).

A gyoori humánszolgáltatások magas színvonalon történô ellátásának mozgatórugója természetesen a város erôs gazdasági bázisa. A gyôri gazdaság és az itt múködô vállala- 


\section{Tudományos múhely}

tok vizsgálata szintén kedvelt témája volt az utóbbi évek kutatásainak. Rechnitzer (2014) a gyốri gazdaság pályapontjait mutatja be és elemzi a rendszerváltástól napjainkig, továbbá feltérképezi a Gyôr-kód (Rechnitzer, 2016) mögött rejtôzố helyi sajátosságokat a gazdasági, a kulturális és a társadalmi tôke szemszögéból. A Gyôri Együttmúködési Modell egyik legújabb vizsgálata kiemelte, hogy a szoros együttmúködés nemcsak a város, hanem a régió versenyképességének növelésében és az infrastruktúra fejlesztésében is meghatározó szerepet tölt be (Fekete, 2018b). A Gyôrben zajló folyamatok további vizsgálatai a gazdasági kormányzás felé való elmozdulást emelték ki (Fekete, 2018a). A helyi gazdaság nem múködne a gazdasági szereplốk pozitív hozzáállása nélkül, így a vállalatok több szempontból való vizsgálata sem maradt ki az elmúlt évek tudományos kutatásaiból. Czakó és Hajdu-Smahó (2014) vizsgálata a vállalati nyitottságra irányult, Reisinger (2014b) a vállalatok kapcsolati hálóját térképezte fel. A város jövôbeli fejlôdési irányait nagymértékben meghatározza a Modern Városok Program (Fekete, 2018c; Fekete, 2019), mely azonban kevésbé érinti a szociális szektort.

\section{AZ ÖNKORMÁNYZATI LAKÁSGAZDÁLKODÁS MAGYARORSZÁGON 1990 UTÁN}

Gyôr lakásügyi politikájának megismerése elôtt érdemes kitérni az 1990-es évek elôtti idôszakra, folyamatokra is, hiszen a rendszerváltás gyökeres változást hozott a lakásgazdálkodás területén is. A második világháborút megelôzố idôszakban az állami bérlakásszektor viszonylagos fejletlensége volt jellemzô, bár néhány nagyobb állami vállalat tartott fenn dolgozói számára kedvezményes szolgálati lakást, de a bérlakások döntố hányada magántulajdonban volt, és a lakbéreket is elsôsorban a piac határozta meg (Kovács, 1992). A második világháború utáni idôszakban az állami bérlakásszektort gyökereiben is más folyamatok határozták meg, mint a korábbi lakásviszonyok teljes átalakításának igénye, vagyis a „tôkés bérlakásszektor" megszüntetése, a gyors kisajátítások, melynek révén a nagyobb városokban az állam vált az elsô számú ingatlantulajdonossá, valamint az új lakáspolitika, mely a valóságban ingyenes lakáshoz jutást és jelképes lakbéreket jelentett. A szocializmus éveiben kialakult bérlakásrendszer gyakorlatilag „felülírta” a klasszikus értelemben vett bérház fogalmát, hiszen egy sajátos forma létrehozásával a lakások kikerültek a piaci forgalomból, és a társadalom jutalmazási rendszerét szolgálták, szinte állami monopóliumként múködött a lakások elosztása, a többlakásos lakóházak építése és fenntartása (Nárai, 1998).

A lakásépítések számát tekintve, a legtöbb lakás Magyarországon az 1970-es években épült, melyeknek közel kétharmada tanácsi lakás volt, és szorosan kapcsolódott az 1960 és 1975 közötti időszakra elfogadott 15 éves lakásépítési tervhez, majd az 1980-as évekre az állam teljesen kivonult a lakásépítések közvetlen finanszírozásából (Czirfusz-Pósfai, 2015), ekkortól váltak jelentôssé a lakossági lakásberuházások. Az állam átgondolta korábbi lakáspolitikáját, többszörös lakbéremelést hajtott végre, és jelentôs engedményeket tett a magánszektor felé. Egyes szerzôk szerint a rendszerváltás elốtti idôszakot a kelet-európai országok többségében egy sajátos modell jellemezte a lakásszektor tekintetében, melynek az volt a lényege, hogy az állam e szektor keresleti és kínálati oldalát is a kezében tartotta (Hegedús-Várhegyi, 1999). Fontos továbbá kiemelni, hogy a világháborút követô három évtôl kezdve, az 1948 és 1990 közötti idôszakban klasszikus értelemben vett szociálislakás-politikáról egyáltalán nem beszélhetünk, és a hatvanas évek végén, hetvenes évek elsô felében az állami lakáselosztások elônyei sokkal inkább a társadalom tehetôsebb rétegeit érintették (Farkas-Szabó, 1995).

A régi lakásgazdálkodási jogszabályok 1990-ben lényegében megszúntek, azonban az új jogszabályi és intézményi keretek megalkotására csak jelentôs késéssel 


\section{Tudományos múhely}

került sor, és mindez a gyakorlatban azt is jelentette, hogy az önkormányzati lakásgazdálkodásban úr keletkezett (FarkasSzabó, 1995). A feladat új gazdájaként a frissen megalakult helyi önkormányzatok hatásköre volt ugyanis eldönteni, hogy a lakásgazdálkodás területén folytatják-e a korábbi gyakorlatot, vagy új megoldásokkal próbálkoznak. Azonban a gyakorlat azt mutatta, hogy az önkormányzatok egyértelmúen elvetették a korábbi módszereket, viszont új elvek, formák még jó ideig nem alakultak ki.

Az új jogszabály' (a továbbiakban: Ltv.) elfogadására 1993-ban került sor, melynek preambulumában megfogalmazott célok között az alábbiakat találjuk: a lakások és helyiségek bérletére vonatkozó szabályok egységesítése, valamint egyszerúsítése; a lakásokkal való észszerúbb, a piaci viszonyokhoz igazodó gazdálkodás jogi feltételeinek megteremtése; továbbá a bérlakásrendszer ellentmondásainak fokozatos megszüntetése a polgári jog alapelveit szem elôtt tartva - az önkormányzatok bérbeadói jogait erôsítve, és a bérlók méltányos érdekeinek védelmét érvényesítve. Magyarországon a köztulajdonú bérlakásokkal való gazdálkodás alapvetốen a helyi önkormányzatok hatásköre, mivel ók a lakások tulajdonosai (kivételt a Nemzeti Eszközkezelố által felvásárolt lakások jelentik). Tulajdonosként a helyi önkormányzat rendkívül nagy szabadsággal rendelkezik a lakásgazdálkodás kereteinek és feltételeinek meghatározásában, melyet az önkormányzat saját, helyi rendeletében szabályoz. A bérlakásállomány fenntartásának költségei viszont a kezdetektől nagyrészt az önkormányzatokra hárultak, sốt az önkormányzat ez irányú feladatellátását támogató állami források folyamatos szúkülése is tetten érhetô volt (Vígvári, 2008).

Az 1990-es évek meghatározó lakáspiaci mozgásai az állami tulajdonú lakásállomány átadása volt az önkormányzatoknak, majd pedig a lakásállomány privatizációja. Nem túlzás azt mondani, hogy a rendszervál- toztatás utáni elsố öt év egyetlen, alapvetô változásokat hozó eseménye az önkormányzati tulajdonú lakásszférában a privatizáció volt. A privatizáció elindulásakor országosan $19 \%$ volt az önkormányzati tulajdonú lakások aránya a teljes lakásállományon belül (Budapesten 61\%), ez az arány az 1990-es évek közepére országosan 3\% alá csökkent, megjegyezve, hogy a privatizáció kisebb mértékben, de ma is folyamatosan zajlik (Czirfusz-Pósfai, 2015). A privatizációval egyidejúleg, már az 1980-as évektôl kezdve megfigyelhetố jelenség az önkormányzati bérlakásszektoron belül a rezidualizáció, ami azt jelenti, hogy a lakásállomány méretének csökkenésével párhuzamosan csupán a legrászorultabb társadalmi csoport lakhatását hivatott szolgálni a szektor a lakhatás megfizethetôségével kapcsolatos általánosabb társadalompolitikai célkitúzések helyett. A privatizációs folyamatok egyúttal felerôsítették az egyes társadalmi csoportok közötti egyenlőtlenségeket is, hiszen a jellemzôen magasabb státuszú bérlôk megvásárolták a legértékesebb lakásokat, kikerülve így a nem piaci bérlakásszektor bérlói közül, az önkormányzatok tulajdonában pedig jellemzóen az alacsonyabb értékú, rosszabb állapotú lakások maradtak, melyekben a szegényebb, alacsony társadalmi státuszú bérlôk laktak. Egyes vélemények szerint az 1989-1990 során lezajlott elsô privatizációs szakasz inkább egy ajándékozási aktusnak tekinthetô, mint privatizációnak, ugyanis lehetôséget biztosított nagy értékú, drága ingatlanok áron alul történô megvásárlására (Kovács, 1992). Továbbá érdemes megjegyezni, hogy az 1990-es években a lakásszektorban lezajlott folyamatok esetében nem beszélhetünk klasszikus értelemben vett privatizációról, mivel a lakást a bent lakó bérlốk vették meg (Farkas-Szabó, 1995).

A privatizáció eredményeképpen kialakuló negatív folyamatok az önkormányzati lakásszektorban a további években sem tûntek el, a tendencia tovább folytatódott, a 2008-as gazdasági világválság után felgyor- 


\section{Tudományos múhely}

sult és felerôsödött, valamint azt sem szabad elfelejteni, hogy mindemellett a magyarországi lakásgazdálkodás kényszerpályán van (Czirfusz-Pósfai, 2015). E mögött több háttértényezó is megfigyelhetô, mint az átfogó, országos lakáspolitika hiánya; a települési önkormányok nagy szabadsága a helyi lakáspolitika meghatározásában; vagy éppen az a tény, hogy jelenleg az önkormányzatok gyakorlatilag semmilyen költségvetési támogatást nem kapnak lakásállományuk fenntartására. Az 1990-es önkormányzati törvény által a helyi szintre delegált lakásgazdálkodási feladatokat a 2011-es új önkormányzati törvény is helybenhagyta, nem változtatta meg. Általánosságban az 1990-es évektól kezdve elmondható, hogy az önkormányzati bérlakásállomány a lakások minôségét és a benne lakók társadalmi státuszát tekintve a magyar lakásállomány legalacsonyabb presztízsú része (FarkasSzabó, 1995). Azonban a bérlakásokkal és a szociális bérlókkel kapcsolatos lefelé tartó verseny a kétezres években is tovább súlyosbodott. Mindennek egyik eleme volt, hogy a szociális ellátásokhoz kapcsolódó kötelezettségek - például a segélyezések egyes elemei - helyi szintre való delegálása valósult meg. Általános tendenciaként az is megfigyelhetô, hogy egyes önkormányzatok a lakásállományuk további leépítésére és a bérlôk társadalmi státusz szerinti szelektálására törekednek, így a lakásállomány szociális funkcióját sem tudja betölteni, azzal szemben, hogy a rendszerváltást követô privatizációs folyamatok során kifejezett közpolitikai szándék volt (Czirfusz-Pósfai, 2015), hogy az állami lakásszektorból szociális lakásszektor váljon, ami azoknak biztosít lakhatást, akik azt piaci alapon egyáltalán nem tudják megoldani. Mindezekhez szorosan kapcsolódó jelenség, hogy az önkormányzati bérlakásokhoz való hozzáférés lehetôségei területileg rendkívül differenciáltak, valamint ezek a lehetôségek folyamatosan beszúkülnek - a lassabb ütemben folytatódó privatizáció és a legrosszabb állapotú lakások szanálása révén.

\section{A GYỐRI ÖNKORMÁNYZAT LAKÁSÜGYI POLITIKÁJA 1990 UTÁN}

Az 1990-ben elfogadott önkormányzati törvény ${ }^{2}$ a lakásgazdálkodást önkormányzati feladatként definiálja a helyi közszolgáltatások körében, azonban a települési önkormányzat maga határozza meg, mely feladatokat, milyen mértékben és módon látja el. Az 1991-es jogszabály³ szerint az önkormányzat tulajdonába kerülô lakásállomány nagy terhet és óriási feladatot jelentett az önkormányzat számára, tekintettel arra, hogy jelentôsen elmaradt a felújítás mértéke, és nem megfelelóen rendezettek a lakbérek. ${ }^{4} \mathrm{Az}$ állami szerepvállalás csökkenése a lakásgazdálkodás területén nem oldotta meg a problémákat, csupán továbbadta a tulajdonlás terheit.

Az 1993-ban elfogadott lakástörvény Gyơrben is alapvetô változásokat eredményezett a lakásszektorban, melynek következtében egyrészt a bérlók vételi joga miatt a korábbi bérlakásszám a harmadára csökkent, másrészt a lakásállomány összetétele is jelentôsen megváltozott, hiszen a bérlôk a jobb állapotú, fơként lakótelepi lakásokat vásárolták meg (Kovács, 2000). Megállapítható, hogy a lakások nagymértékú privatizációja Gyốr városát sem kerülte el, hiszen míg 1993-ban a településen 14652 önkormányzati bérlakás volt, ami a város lakásállományának 30\%-át tette ki, addig 1997-ben 5558 lakással rendelkezett az önkormányzat, ami 11,2\%-ot jelent (Nárai, 1998). A többi megyeszékhely településhez hasonlítva Győrben csökkent leginkább a bérlakások aránya, azonban a város ennek ellenére is megôrizte a vezetố pozícióját a többi megyeszékhelyhez képest. Mindennek okát abban érdemes keresni, hogy az önkormányzat tulajdonát képezố bérlakások jelentốs része nem adható el, mert múemlék épületben található.

Az 1993-as lakástörvény nyomán a lakásgazdálkodási politikát is szükséges volt újragondolni. A gyôri önkormányzat hamar felismerte, hogy valamilyen formában el 


\section{Tudományos múhely}

kell kezdeni a privatizált lakások pótlását, és meg kell határozni a szerepvállalását a lakásügyi szektorban. Ebben a szellemiségben az önkormányzat 1995-ben fogadta el lakáskoncepcióját, mely szerint a lakások kötelezô privatizációján túl nem kívánja a lakásállományát értékesíteni, valamint a lehetôségeihez mérten gondoskodni kíván a lakosság legszegényebb, legelesettebb, illetve krízishelyzetben lévố rétegeinek ellátásáról, ${ }^{5}$ tehát az önkormányzat nem tudja, és nincs is szándékában, hogy a város lakásellátásának megoldását teljeskörúen magára vállalja. Célként jelenik meg a szociális rendszer és a lakásgazdálkodás összehangolása, illetve a magánerôs építkezési kedv növelése, mely utóbbit különbözô kedvezmények biztosításával kívánja ösztönözni. Ez a gyakorlatban azt jelenti, hogy az önkormányzat gondoskodni szándékozik építési telkek kialakításáról, kamatmentes visszatérítendô támogatási formával segíti az építkezôket és a lakásvásárlókat, valamint szociális bérlakásokat tart fenn és létesít. A pénzbeli támogatások mellett az önkormányzat természetbeni segítségnyújtás kidolgozását is előirányozta, mely jogi és pénzügyi tanácsadásra, valamint építkezések szervezésére és lebonyolítására terjedt ki. Kiemelt szerepet szánt továbbá az elốtakarékosságnak, mely az albérletben lakóknak teszi lehetôvé a késôbbi lakásszerzést. A koncepcióban két társadalmi csoport, a fiatalok és az idôsek élveznek prioritást. Míg az elôbbi csoport esetében otthon jellegú lakások építését irányozza elő, utóbbi csoport tekintetében a nyugdíjasházi rendszer bôvítését célozza meg. A koncepció megfogalmazta továbbá a lakásigénylési rendszer felülvizsgálatának szükségességét. Mindez a gyakorlatban azt jelentette, hogy megszüntették a korábbi közel 3000 lakásigénylést, és a helyi rendeletben meghatározott feltételek szerint a továbbiakban szociálislakás-kérelmet lehetett benyújtani, melyet a környezettanulmány és egyéb körülmények feltérképezése után a Lakásügyi Bizottság bírált el (Kovács, 2000). A lakáskoncepció elfogadása után egy évvel, azzal összhangban kidolgozták a lakásépítésekre vonatkozó programjavaslatot is. ${ }^{6}$ Mindkét koncepcionális dokumentum a lakásellátás területéhez kapcsolódó feladatokat határozta meg az 1996 és 2001 közötti idôszak tekintetében. A koncepciókban megfogalmazott vállalások az alábbi részterületeket ölelték fel: ${ }^{7}$

1) Bérlet útján hasznositható, otthon jellegú lakások épitése (Fiatalok Háza Program). Már a koncepció elfogadása elótt, 1993-ban megtörtént a Szent Imre úti volt szovjet tiszti lakások felújítása és e 92 lakás hasznosítása. A javaslatban további 120 lakás megépítését rögzítették. Ennek keretében 1996-ban a Mészáros Lốrinc utcai, volt GYÁÉV-munkásszálló átalakítására került sor, 55 lakást alakítottak ki, 1997-ben a Szigethy Attila utcai kollégium átalakítása és bôvítése révén készült el a 30 lakásos garzonház, valamint 1998-ban a Zöld utcában elkészült egy 45 lakásos ifjúsági garzonház is. A Fiatalok háza program keretében ezeket a lakásokat olyan fiatalok, fiatal házasok bérelték, akik vállalták az elótakarékosságot és az öt év idôtartamú bérleti idôt, mely idôtartam nem hosszabbítható.

2) Az emberi életpálya végén az Önkormányzat nyugdíjasház elhelyezés formájában nyújt biztonságot az idôs emberek számára (Idôsek Háza Program). Az önkormányzat a Kálóczy téren 90, a Rónai Jácint utcában 79 nyugdíjasházi garzonlakással rendelkezett, melyhez a koncepciók további 60 lakás megvalósítását tûzték ki célul. Az igények kielégítésében jelentôsen segített, hogy 1997-re Marcalvárosban felépült a 90 lakásos Szent Anna Otthon, mely egyházi intézmény, fenntartója a Szentlélek Templom és Otthonfenntartó Alapítvány, azonban az intézmény létrejöttében részt vállalt az önkormányzat is, hiszen biztosította az építési telket és a közmúvesítést. 1999-ben tovább bôvült az otthon, további 65 lakóegységgel.

3) Speciális jellegú lakások épitése, melyek a lakásgondjaikat önállóan megoldani nem képes, halmozottan hátrányos helyzetúek problémájának enyhítését szolgálják. 


\section{Tudományos múhely}

- Jóléti Épitốk Program. Az országos programot a Jóléti Szolgálat Alapítványból létrejött Jóléti Építôk Kht. kezdte meg, melyhez 1997-ben Győr is csatlakozott. A részvétel feltétele volt, hogy az önkormányzat a Kht.nak kedvezményes áron biztosítson közmúvesített építési telket, valamint a pályázónak kamatmentes építési kölcsönt, továbbá múködjön közre a leendô építók kijelölésében. A program keretében 1998-ban megkezdódött egy kilenclakásos épület kivitelezése az Achim András utca 6. szám alatt, azonban a program nem haladt zökkenómentesen, így a kilenc lakás megépülte és értékesítése után az önkormányzat tovább nem kívánt részt venni a programban.

- Fejleszthetô önkormányzati lakások. E lakásépítési forma programba kerülését az indokolta, hogy a városban jelentôs olyan lakáshoz jutási igény jelentkezett, melyeket alacsonyabb komfortfokozatú, felszereltségú lakásokkal is ki lehet elégíteni. A fejleszthetôség arra utal, hogy a lakások olyan színvonalon, felszereltséggel épülnek, melyek az OTÉK-nak (országos településrendezési és építési követelmények) megfelelnek, azaz a minimumkövetelményeket kielégítik, azonban a leendô bérlố igénye és anyagi lehetôsége függvényében a lakások belsố felszereltsége javítható. 1998-ban a Kinizsi Pál utca 27. szám alatt hat ilyen bérlakást építtetett az önkormányzat, valamint húsz ilyen lakás építését irányozta elô az 1999-es évre.

- Szociális Lakásépitési Program. Ez a lakásépítési forma a kevés induló tókével rendelkezô családok közül is kiemelten támogatja: a szociálisan hátrányos helyzetú, a volt állami gondozott családos fiatalok, a fogyatékos és egészségkárosodott személyeket gondozó családok, nagycsaládosok elsố saját tulajdonhoz jutását. A kísérleti mintaprogramhoz Gyốr város önkormányzata is csatlakozott, vállalva az alábbi feltételeket: ingyenes közmúvesített telek biztosítása, kamatmentes lakásépítési kölcsön biztosítása, közremúködés a leendô építtetốk kiválasztásában, a generálkivitelezốk megkeresésé- ben, valamint a lakásépítés szervezésében való hatékony részvétel. ${ }^{8} \mathrm{Az}$ önkormányzat a közgyúlés döntése szerint 500 ezer forint vissza nem térítendô támogatást nyújtott a programban részt vevố családok számára, e mellé jelentôs állami támogatás - lakáshoz jutási támogatás - is járt. ${ }^{9}$ A program keretében a lakások építése a leendố tulajdonosok feladata, a leendó építtetôket az Önkormányzat Lakásügyi Bizottsága választja ki. A programot a Győr-Moson-Sopron Megyei Cigányok Érdekvédelmi Szövetsége kezdeményezte, azonban a koncepciókban elóirányzottak alapján a program elindítására még 1999-ben sem került sor, mivel az érintett területek lakossága (Újváros, Szabadhegy, Bácsa) tiltakozott az építkezések megkezdése ellen.

Az alábbi programok, kezdeményezések tekintetében 1999-ben a Közgyúlés az alábbi határozatokat hozta: ${ }^{10}$ A Jóléti Építôk Program keretében további lakásépítést nem tart indokoltnak, az Idôsek Háza Programot egyelőre befejezettnek tekinti, azonban felmérést készít az igényekről, és ennek ismeretében tesz javaslatot a folytatásra. A Fiatalok Háza Program folytatását támogatja, ugyanígy a fejleszthetô önkormányzati lakásépítési formát is, továbbá támogatja a Szociális Lakásépítési Program beindítását. A fenti, nagyobb programokban nem szerepelt, de a lakásgazdálkodás további jelentôs feladataként jelenik meg a bérlakásvásárlás is. ${ }^{11}$ A programok pénzügyi fedezetét a lakásértékesítésbôl befolyt bevételek jelentették, ugyanis az 1993-as Ltv. idevonatkozó bekezdése ${ }^{12}$ szerint az önkormányzat a lakóépületek elidegenítéséból származó bevételeit lakáscélokra és az ezekhez kapcsolódó infrastrukturális beruházásokra használhatja fel. Az önkormányzat lakásgazdálkodásában vállalt szerepének fontosságát jelzi, hogy a város költségvetésében 1995 óta jelennek meg önálló tételként a lakáscélú kiadások.

2004-ben az önkormányzat egy múszaki fenntartási és ingatlanfejlesztési programot $^{13}$ fogadott el a 2005 és 2014 közötti idó- 


\section{Tudományos múhely}

szakra, mely az önkormányzat kizárólagos tulajdonában lévố épületeire vonatkozott. A program célja ezen épületek múszaki és használati értékének megórzése, illetve növelése volt. A program az épületeket a hoszszú távú fenntartás szempontjából a következó csoportokba sorolta:

- Megfelelő épületek: általában 1970 után épültek, vagy teljes felújításon estek át. Itt célként a múszaki állapotuk megtartása jelenik meg.

-Felújítandó épületek: múszaki állapotukat illetốen jelentôsen elhasználódott lakásokról van szó, melyek karbantartással nem hozhatók megfelelô színvonalra, így felújításuk/átalakításuk/korszerúsítésük szükséges. Múemléki, illetve helyi védettség alatt álló, a városképi megjelenés szempontjából meghatározó épületek ezek, továbbá még gazdaságosan felújítható, nagyobb értéket képviselố épületek, melyek 1970 eloótt épültek, illetve felújításon estek át).

- Bontandó épületek: a városrendezési célok miatt bontásra ítélt épületek.

- Ingatlanfejlesztésre javasolt épületek: olyan épületek, melyek a meglévố kedvezôtlen adottságaik, illetve az elmulasztott felújítások miatt már alig használhatók, felújításuk nem gazdaságos, tehát elbontásuk szükséges, és a kialakult beépíthetô telek hasznosítható.

A lakásállomány összetételét tekintve a lakások egyharmada megfeleló állapotban van, míg egyötöde a lebontandó, illetve az ingatlanfejlesztésre javasolt épületek körébe tartozik. A győri önkormányzat 2007-ben alkotta meg és fogadta el új lakáskoncepcioját, ${ }^{14}$ melyben kiemeli, hogy a rendszer továbbra sem önfenntartó, hiszen a lakásbérleti díjak nem fedezik a hosszú távú fenntartás költségeit, így a valós fenntartási költségek és a ténylegesen megfizetett lakbérek meglehetôsen eltérnek egymástól, a kettố különbségét nemcsak a szociálisan rászorulók kapják, hanem mindenki, aki korábban bármilyen jogcímen bekerült ebbe a körbe. Megfogalmazza továbbá, hogy a rendszer számos gyakorlati ellentmondást is magában foglal:
- Az önkormányzat jelentôs teherrel kapta meg a lakásállományt, a felújításukra nem került sor, a jobb minôségú lakásokat az arra jogosultak többnyire megvásárolták.

- A lakások fenntartási költségei nôttek, a felújítások elmaradtak, így a múködést napi szinten kell biztosítani.

- A tényleges új szerzôdések száma alacsony, a lakásállomány 2-2,5\%-át teszik ki, ennek oka a megüresedések alacsony száma.

- A város korábbi költségvetésében szerepló lakásalap kimerült, mivel a fejlesztési célú beruházások megvalósultak, viszont a tervezett bevételek nem realizálódtak.

A koncepció megállapította, hogy az önkormányzatnak a lakásszektorban leszúkült a mozgástere, a meglévô épületek múszaki állapota folyamatosan romlik, nincs lehetôség új programok indítására, valamint csökkent a fiatalok önálló lakhatáshoz jutási támogatása is. Mindezek szükségessé tették a város lakáskoncepciójának felülvizsgálatát.

A koncepció külön kitér a határozatlan idejú lakásbérleti szerzódésekkel kapcsolatos problémára is, mely lakások holttôkét jelentenek, és szükséges a hasznosításuk lehetôségét átgondolni. Önkormányzati bérlakásban kétféle típusú szerzôdéssel lehet lakni: meghatározott ideig szóló határozott idejú szerzôdéssel, illetve idôponthoz nem kötött határozatlan idejú szerzôdéssel. A határozatlan idejú szerződéseket 1994. január elseje (az Ltv. hatálybalépése) elôtt kötötték meg, ezen idôpont után ugyanis csak határozott idejú szerzódések megkötésére van lehetôség. Itt csupán a bérleti jogviszonyok folytatása, a cserék és a csereelhelyezések jelentenek kivételt, azonban a korábbi szerződéses jogviszonyok itt is 1994 előttiek. A határozatlan idejú bérleti szerzôdéssel rendelkezô lakások kevés kivételtól (felmondási okok, bérlô esetleges halála utóbbi esetben is van lehetôség, hogy közeli hozzátartozó, eltartó a bérleti jogviszonyt folytassa) eltekintve csak akkor kerülnek vissza az önkormányzathoz újraelosztásra, ha a bérlố a bérleti jogviszonyát saját elha- 


\section{Tudományos múhely}

tározásából megszünteti. Ezen lakások esetében tehát a mobilitás nagyon alacsony, a bérlők nem igazán éreznek késztetést arra, hogy lakhatásukat önállóan megoldják, sôt sok esetben akkor is megtartják maguknak az önkormányzati lakást, ha további tulajdonnal rendelkeznek. Mindezekbôl és más városok gyakorlataiból kiindulva a koncepció részletesen áttekinti a lakások jövôbeli értékesítésének szempontjait és feltételeit. A koncepció az alábbi bérlakástípusokat nem javasolja értékesítésre: a nyugdíjasházban elhelyezkedô lakások; a fiatalok házában elhelyezkedô lakások; garzonházakban elhelyezkedô lakások; az ingatlanfejlesztési célú területeken lévô lakások; a városrendezési okból bontásra ítélt épületekben lévő lakások; a 15 évnél nem régebben felújított vagy épült lakások; intézményi szolgálati lakások. Javasolja értékesítésre a határozatlan idejû szerződésekkel rendelkezó lakásokat, illetve határozott idejú szerzôdéssel rendelkezô lakásokat csakis szigorú szabályok mellett abban az esetben, ha a lakás olyan épületben van, amit a magas fenntartási, üzemeltetési, esetleg felújítási költségek miatt nem akar megtartani az önkormányzat.

Az értékesítési bevételek felhasználásának felülvizsgálata során megállapították, hogy a lakások eladásából származó bevételek forrásul szolgálhatnak az önkormányzat által támogatandó, alábbi célokhoz: fiatal családok életkezdését szolgáló, időseknek biztonságot nyújtó, szociális helyzet alapján bérelt lakások számának növelésére; meglevố és megmaradó épületek, lakások múszaki állapotának javítására; elsô lakást szerzôk kamatmenteskölcsön-támogatására; ifjúsági építési telkek kialakítására.

Mindezek alapján megállapítható, hogy az új lakásügyi koncepció továbbra is fenn kívánja tartani az 1993-ban indított Fiatalok Háza Programot, azonban a program átgondolást igényel, ugyanis a kétezres években jelentôsen lecsökkent az elôtakarékos pályázók száma. A Nyugdíjasház (korábban Idôsek Háza) Program Gyôr lakáskoncepciójának hosszú távon megtartandó, illetve középtávon bôvítendő eleme. Felülvizsgálatot igényel a bekerülést megelôzô orvosi vizsgálat rendszere, illetve az idôsgondozással való összekapcsolás lehetósége. A nyugdíjasházak fontos szerepet töltenek be az önkormányzati lakásgazdálkodásban is, hiszen a lakásmobilitás tekintetében ily módon bérlakások kerülhetnek vissza az önkormányzathoz, illetve az önkormányzat elôvásárlási joga révén lehetôség van a nyugdíjasházba költözôk lakásainak megvásárlására.

A korábbiaktól eltérô, kvázi új típusként jelenik meg a szociális célú lakások típusa. A szociálisan nehezebb helyzetben lévô, tulajdont szerezni nem tudó, de lakást fenntartani képes lakosok támogatása érdekében szükség van önkormányzati lakás vásárlására. Új elemként jelennének meg a kiléptetô házak, melyek lényege, hogy önkormányzati területen, önkormányzati beruházással épülnek olyan házak, sorházak, melyek alapvetô szolgáltatást nyújtanának a bérlók számára, azonban a lakhatás biztosítása mellett a bérlôk életvitelét szociális munkások segítenék, megteremtve annak a lehetôségét, hogy a családok késôbb másik bérlakásba tudjanak költözni. A koncepció továbbra is fenn kívánja tartani az elsô lakást szerzôk önkormányzati kamatmenteskölcsön-támogatási rendszerét, azonban a tulajdonszerzési formák, igények és a költségvetési lehetôségek figyelembevételével a támogatási rendszer átgondolására van szükség. A koncepció szükségesnek ítéli ifjúsági épitési telkek kialakítását, melynek keretében az önkormányzat, saját területei igénybevételével, elő-közmúvesítéssel piacilag kedvezô áron építési telkeket alakítana ki, mely telkeket pályáztatással értékesítenék elsôsorban fiatalok részére. Az önkormányzati tulajdonú épületek múszaki állapotának javítása a hosszú távú, folyamatos múködóképesség megtartásának alapvetô feltétele. Felújítással számolna az összes önkormányzati tulajdonú bérlemény 50\%-ában, ideértve a múemléki és helyi védettség alatt álló épületeket, a városképi megjelenés szempontjából meghatározó épületeket, továbbá a még gazdaságosan 


\section{Tudományos múhely}

felújítható, nagyobb értéket képviselô épületeket, melyek általában az 1970 eloótt épült vagy felújított épületek.

2007-ben a határozatlan idejú szerzôdéssel rendelkezô önkormányzati lakások értékesítésének átgondolásával új rendelet ${ }^{15}$ született, mely szerint a lakások a közgyúlés külön döntése alapján értékesíthetôk, az elidegenítésre szerzôdéses elôvásárlási jog gyakorlása útján van lehetôség. Továbbá fontos kiemelni, hogy a magyar Államot minden más jogosultat megelôzố elôvásárlási jog illeti meg. Határozatlan idejú bérleti szerzốdéssel rendelkezố lakások esetén a vételár a forgalmi érték megállapítása során figyelembe vett, a bérló által a lakásra fordított és meg nem térített, a beszámítással el nem ismert és igazolt értéknövelô beruházások értékével csökkentett beköltözhetô forgalmi érték 70\%-a.

A kétezres évekbôl fontos továbbá kiemelni a gyôri lakásügyi politika két meghatározó elemét. Egyrészt Győr-Újváros területén elindult a szociális városrehabilitáció, mely a mai napig tart, és a projektek révén önkormányzati bérlakások is megújultak (Fekete-Laczkovits-Takács, 2019a; 2019b). Az elsố ütemben 40, a második ütemben 18, a harmadik ütemben 15 modern szociális bérlakás kialakítása valósulhat(ott) meg. Másrészt Gyôr Sárás városrészének területén két ütemben, 2016-ban és 2018-ban szociális bérlakások épültek. Összesen 26, mindegyik másfél szobás, és $49 \mathrm{~m}^{2}$ alapterületû, mely típusra a beadott lakáskérelmek alapján mind szobaszám, mind méret tekintetében a legnagyobb szükség volt.

\section{A GYÔRI ÖNKORMÁNYZAT HATÁLYOS LAKÁSÜGYI FELADATAI}

Az új önkormányzati törvény ${ }^{16}$ (a továbbiakban: Mötv.) a továbbiakban is helyi önkormányzati feladatként definiálja a lakás- és helyiséggazdálkodást. Gyôr Megyei Jogú Város Önkormányzata rendeletében ${ }^{17}$ a lakásgazdálkodás területén kötelezó feladatként fogalmazza meg az önkormányzati tulajdonban lévô lakások és helyiségek hasznosítását (bérbeadás, értékesítés, csere, jogutódlás elismerés stb.) a bérbeadói jogokat gyakorló Gyôr-Szol Zrt. közremúködésével, valamint önként vállalt feladatként írja le a lakásvásárlási és -építési támogatások biztosítását. Az önkormányzat által ellátott lakásgazdálkodási feladatellátás részleteit a helyi rendelet tartalmazza. ${ }^{18}$

A rendelet szerint a bérlakásban történố elhelyezés, illetve azt megelózóen a jogosultság megállapítására vonatkozó eljárás kérelemre, formanyomtatvány benyújtásával indul, kivételt jelent ez alól a pályázat útján elnyerhetô bérlakás, ahol az eljárás pályázati nyomtatvány benyújtásával indul. A pályázat, illetve kérelem benyújtásánál többek között az alábbi általános rendelkezések az irányadók. Pályázatot, kérelmet házas- vagy élettársak csak együttesen nyújthatnak be. Számos esete van annak, amikor a benyújtott pályázat, kérelem nem hagyható jóvá. Ilyen eset, ha a pályázatot, kérelmet benyújtó család vagy annak bármely tagja egyketted tulajdoni hányadot meghaladó, lakhatás céljára szolgáló ingatlantulajdonnal rendelkezik; öröklési szerződéssel rendelkezik (tartási, életjáradéki vagy ingatlan tulajdonjogának megszerzése tárgyában); valamint kizárólagos haszonélvezeti joggal rendelkezik (ingatlannak legalább egy lakásegységet kitevô tulajdoni hányadát tekintve). Külön szabálycsoport vonatkozik az olyan pályázókra, kérelmezốkre, akik az önkormányzattal aktuálisan, illetve korábban bérleti jogviszonyban állnak/álltak. Ezek alapján kizáró ok az elbírálásnál, ha valaki önkormányzati bérlakás bérleti jogával rendelkezik, ez alól kivételt képez az átmeneti elhelyezés, valamint a mozgáskorlátozottak számára kialakított bérlakásra, valamint nyugdíjasok házában történô elhelyezés iránti pályázat, illetve kérelem. Kizáró tényezố továbbá, ha a pályázó, illetve kérelmezô:

- a benyújtást megelózó tíz éven belül bérlakást kedvezményesen vásárolt, vagy elôvásárlási jogáról lemondott, 


\section{Tudományos múhely}

- a benyújtást megelôzó tíz éven belül bérlakást pénzbeli térítéssel visszaadott vagy magántulajdonra cserélt,

- a benyújtást megelózô tíz éven belül bérleti jogát neki felróható okból a bérbeadó felmondással megszüntette, vagy bérlótársi jogát a bíróság megszüntette, vagy a tulajdonosi jog gyakorlója nem járult hozzá az újabb határozott idejú szerzốdés megkötéséhez,

- az általa bérelt lakás kiürítése iránti perben hozott, kiürítést elrendelő döntés jogerôre emelkedésétôl számított tíz év a benyújtásig nem telt el,

- a benyújtást megelôzố öt éven belül lakást adott vissza,

- bérloótársi jogáról lemondott (a benyújtástól számított egy évig nem nyújthat be kérelmet, pályázatot).

Győrben a bérlakásban történố elhelyezésre az alábbi jogcímeken van lehetôség: 1) elôtakarékos pályázat alapján történô elhelyezés; 2) felújításos pályázat alapján történố elhelyezés; 3) mozgáskorlátozottak számára kialakított bérlakások pályázat alapján történố elhelyezés; 4) elôzzetes regisztrációs nyilvántartás alapján történô elhelyezés; 5) szociális bérlakásban történô elhelyezés; 6) nyugdíjasok házában történô elhelyezés; 7) nyugdíjasok házából távozó bérlố elhelyezése; 8) piaci vagy költségelvú lakbérrel történô pályázat; 9) átmeneti elhelyezés; 10) felújítás, átalakítás, korszerúsítés, bontás folytán megszúnố bérlakás bérlójének elhelyezése; 11) városérdek által indokolt feladat vagy városfejlesztési, városrendezési cél megvalósítását szolgáló elhelyezési igény kielégítése; 12) tulajdonosi döntés alapján önkormányzati ingatlan értékesítésének elősegítéséhez szükséges elhelyezés; 13) bírósági ítélet vagy hatósági határozat végrehajtása; 14) társbérlet felszámolása; 15) Gyôr Megyei Jogú Város Önkormányzata által fenntartott intézmény feladatának ellátása; 16) bérlőkijelölési joggal rendelkezô, önkormányzattól független szerv feladatainak ellátása; 17) bérlakás megvásárlásának meghiúsulása következtében megszúnô lakáshasználati jog miatti elhelyezés.

A szociális bérlakásban történô elhelyezés, illetve az elôzetes regisztrációs nyilvántartás alapján történô elhelyezés, valamint a nyugdíjasok házában történô elhelyezés mind szociális rászorultság alapján történő bérbeadás. Nem szociális rászorultság alapján történố bérbeadás körébe tartozik az elôtakarékossággal, a bérlakás felújítására, a mozgáskorlátozottak számára, a piaci vagy költségelvú lakbérrel történố hasznosításra meghirdetett pályázat, az átmeneti elhelyezés, az intézményi bérlakásban történó elhelyezés, valamint a városérdek által indokolt elhelyezés.

Az 1. táblázat tartalmazza a szociális bérlakásban, illetve az elôzetes regisztrációs nyilvántartás alapján történô elhelyezés jogosultsági feltételei közül a jövedelemhatárokat, melyek a család egy fốre jutó havi nettó jövedelmére vonatkoznak. Itt fontos megjegyezni, hogy a jövedelemhatárok

1. táblázat: Jövedelemhatárok a szociális bérlakásban, illetve az elôzetes regisztrációs nyilvántartás alapján történö elhelyezés esetén

\begin{tabular}{l|c|c|c}
\hline & $\begin{array}{c}\text { Egytagú család } \\
\text { esetén }\end{array}$ & $\begin{array}{c}\text { Olyan kéttagú családban, } \\
\text { ahol eltartott személy nem él }\end{array}$ & Egyéb családban \\
\hline $\begin{array}{l}\text { Szociális bérlakásban } \\
\text { történố elhelyezés }\end{array}$ & $56350-112700 \mathrm{Ft}$ & $40250-80500 \mathrm{Ft}$ & $40250-64400 \mathrm{Ft}$ \\
\hline $\begin{array}{l}\text { Elốzetes regisztrációs } \\
\text { nyilvántartás alapján } \\
\text { történó elhelyezés }\end{array}$ & $112700-152950 \mathrm{Ft}$ & $80500-136850 \mathrm{Ft}$ & $64400-99820 \mathrm{Ft}$ \\
\hline
\end{tabular}

Forrás: Saját szerkesztés a 30/2018. (XII. 20.) GYMJVÖ. rendelet alapján 


\section{Tudományos múhely}

2019. január elseje óta a mindenkori minimálbér bruttó összegének meghatározott százalékában kerülnek meghatározásra. ${ }^{19}$ Korábban a mindenkori nyugdíjminimum összegét vették alapul, azonban 2019 elôtt jelentôsen megnôtt azoknak az eseteknek a száma, amikor a bérlakás iránti kérelmet a jövedelemhatár túllépése miatt utasították el, tehát az alacsony munkabéralapú jövedelemmel rendelkezók kiszorultak a bérlakásra jogosultak körébốl. Ennek oka fốként abban keresendô, hogy amíg a garantált bérminimum és a minimálbér minden évben emelkedett, addig a mindenkori öregségi nyugdíj legkisebb összege változatlan maradt.

Az elôzetes regisztrációs pályázat esetén elôször a regisztrációs nyilvántartásba történô felvételrôl születik döntés, majd ennek birtokában a pályázó a pályázati hirdetményben szereplô, pályázható lakásokra nyújthat be pályázatot. A pályázót a hirdetményben meghatározott karbantartási munkák is terhelhetik, melyek elvégzése után kerül sor a bérleti szerzôdés megkötésére elsố alkalommal egy évre.

A szociális rászorultság alapján történố elhelyezés harmadik típusa a nyugdíjasok házában történố elhelyezés, ahol a kérelem jóváhagyása az alábbi rendeleti feltételek teljesítése során lehetséges:

- a kérelmezố a társadalombiztosítási nyugellátásról szóló törvény alapján megállapított ellátásban részesül, vagy az öregségi nyugdíjkorhatárt elérte;

- önmaga ellátására képes;

- a család egy fốre jutó havi nettó jövedelme egytagú család esetén a 208600 Ft-ot, kéttagú család esetén a 163900 Ft-ot nem haladja meg;

- vállalja, hogy a hatályos bérleti szerzôdéssel bérelt lakását kiürítve visszaadja (amennyiben önkormányzati bérlakásban lakik), vagy vállalja, hogy a tulajdonában álló lakás- vagy ingatlanhányad forgalmi értékének 50\%-át, de legalább 1500000 Ft-ot és legfeljebb 3500000 Ft-ot befizet, vagy amennyiben bérlakás bérleti jogával vagy ingatlantulajdonnal nem rendelkezik, akkor $1000000 \mathrm{Ft}$ összeget befizet.

A nyugdíjasok házában elhelyezett bérló a lakhatáson túl térítésmentesen szolgáltatásokat vehet igénybe, így 24 órás gondozói ügyeletet, szükség esetén szakirányú segítséghívást, gyógyszeradagolást és éjszakai ügyeletben tisztázást és egyéb nem rendszeres segítségnyújtást.

A korábban Fiatalok Háza Program néven, az előtakarékosságot elôtérbe helyezô kezdeményezés a mai napig eleme az önkormányzat lakásgazdálkodási tevékenységének. Egy évben kétszer jelenik meg az elótakarékossággal meghirdett pályázat, amiben a pályázó vállalja, hogy a bérleti szerzôdés ötéves idôtartama alatt legalább havi 60000 Ft megtakarítást félretesz az általa választott hitelintézetnél, valamint igazolja, hogy rendelkezik a karbantartáshoz szükséges legalább 300000 Ft összegú megtakarítással.

Népszerú pályázati lehetôség a bérlakás felújitására meghirdetett pályázat, mely során az önkormányzat a rossz múszaki állapotú, megüresedett lakás bérbeadására felújítási munkálatok elốrásával hirdet pályázatot. Pályázati feltétel, hogy a pályázó igazolja, hogy rendelkezik a pályázati hirdetményben szerepló felújítási költség fedezetével, továbbá vállalja az esetlegesen felmerülố többletköltségeket, jövedelemhatár nincs. Bérleti szerzôdés a lakás felújítási munkálatainak elvégzését követôen köthetô.

A gyôri önkormányzat továbbra is támogatja a lakáshoz jutást a kamatmentes önkormányzatikölcsön-támogatás formájában, melyben a lakástulajdonnal nem rendelkezô, nagykorú természetes személy elsô lakástulajdona megszerzéséhez részesülhet. A támogatás Gyôr város közigazgatási területén történô, legalább egy lakóegységet kitevố ingatlantulajdon vásárlásához vagy építéséhez adható, csak egyszer és egyféle jogcímen. Egy- vagy kéttagú család esetén a család egy fóre jutó havi nettó jövedelme nem haladhatja meg a 483000 Ft-ot, egyéb család esetén a 362250 Ft-ot. A rendelet szerint az alábbi esetekben nem nyújtha- 


\section{Tudományos múhely}

tó támogatás: telekvásárlásra; hitelintézeti kölcsön vagy magánhitel kiváltásához vagy elôtörlesztéséhez; haszonélvezettel, jelzálogjoggal, vételi joggal terhelt ingatlan vásárlásához, építéséhez, bôvítéséhez; lakóépület átalakításához, felújításához; önkormányzati tulajdonú bérlakás megvásárlásához; ráépítés esetén, ha a tulajdonos nem járul hozzá, hogy a kölcsön biztosítékául jelzálogjog kerüljön az ingatlanra bejegyzésre.

A kölcsöntámogatás igénylésének további feltétele, hogy a jogos lakásigény mértékét nem haladhatja meg, melyet a 2. táblázat tartalmaz, valamint legfeljebb $120 \mathrm{~m}^{2}$ hasznos alapterületú ingatlan építéséhez, vásárlásához igényelhetô.

\section{2. táblázat: A jogos lakásigény mértéke}

\begin{tabular}{|c|c|}
\hline $\begin{array}{l}\text { Együtt lakók és együtt } \\
\text { költözók száma (fó) }\end{array}$ & $\begin{array}{c}\text { Lakószobák száma } \\
\text { legfeljebb (db) }\end{array}$ \\
\hline 1 és 2 & kettó \\
\hline 3 & két és fél \\
\hline 4 & három \\
\hline 5 & három és fél \\
\hline 6 & négy \\
\hline 7 & négy és fél \\
\hline 8 & öt \\
\hline $\begin{array}{l}\text { minden további } \\
\text { személy esetében }\end{array}$ & további fél szoba \\
\hline
\end{tabular}

Forrás: Saját szerkesztés a 30/2018. (XII. 20.) GYMJVÖ. rendelet 1. sz. melléklete alapján

A kölcsöntámogatást igénylố személynek további feltételeknek is szükséges megfelelni. Nem részesülhet támogatásban az a személy, akinek elôzố lakásának bérleti jogviszonya neki felróható okból szúnt meg; bérlakást kedvezményes feltételekkel vásárolt meg; bérlakásának bérleti joga úgy szúnt meg, hogy vételi jogáról az arra jogosult javára lemondott; a kölcsöntámogatással érintett ingatlanon kívül 50\%-ot meghaladó lakhatás céljára szolgáló ingatlan tulajdonrésszel vagy haszonélvezettel rendelkezik; kérelmében valótlan adatokat közöl; nem rendelkezik a kölcsöntámogatás visszafizetéséhez szükséges jövedelemmel, vagy a munkáltatói hitel nélkül számított önrész nem éri el az ingatlan vételára vagy a kivitelezési költség 10\%-át; a jogügylet tárgyát képezó ingatlan vásárlásához vagy építéséhez egy éven belül kamatmentes kölcsöntámogatást igényelt, és kérelme a jogos lakásigény mértékének túllépése miatt került elutasításra.

A kölcsöntámogatás legmagasabb összege 2 millió Ft, melynek visszafizetési határideje tíz év, azonban a futamidô alatt bármikor kamatmentesen visszafizethető az önkormányzat számára. Az elmúlt évek során, évente az alábbi összegekben ítélt meg az önkormányzat kamatmentes kölcsöntámogatást: 2015-ben 135300000 Ft, 2016-ban 139960000 Ft, 2017ben $153890000 \mathrm{Ft}$, 2018-ban $152200000 \mathrm{Ft}$, 2019-ben 60350000 Ft értékben. ${ }^{20}$

\section{Gyór lakásügyi politikája a koronavírus- járvány idején}

Mindenképpen érdemes rövid kitekintést tenni arra, hogy a koronavírus-járvány idején milyen prioritások jelentek meg a gyốri lakásügyi politikában. Mint a helyi önkormányzatok múködésének minden területét, úgy az önkormányzati lakásgazdálkodás szegmensét is érintették az élet- és vagyonbiztonságot veszélyeztetô, tömeges megbetegedést okozó humánjárvány következtében kihirdetett veszélyhelyzet hatásai. $\mathrm{Az}$ idevonatkozó jogszabály ${ }^{21}$ értelmében veszélyhelyzetben a települési önkormányzat képviselô-testületének feladat- és hatáskörét a polgármester gyakorolta. Gyốr város polgármestere e hatáskörében eljárva a humánjárvány gazdasági következményeinek kezelése érdekében több rendelkezést hozott, mely érinti egyrészt a helyiség-, valamint a lakásgazdálkodás területét. A 2020. március 11-én kihirdetett veszélyhelyzetre tekintettel az intézkedések elsô csomagja ${ }^{22}$ 2020. április 1-jén lépett hatályba, és az alábbiakat tartalmazta: 


\section{Tudományos múhely}

- a szociális lakás bérlójét 2020. április 1 . és augusztus 30. között díjfizetési kötelezettség nem terhelte (illetve a veszélyhelyzet korábbi megszúnésének idôpontjáig),

- az élelmiszert, az illatszert, a drogériai terméket árusító vagy a sorsolásos játék, fogadások, távszerencsejáték és lottójáték értékesítésével foglalkozó üzlet, a banki, biztosítási vagy pénzügyi szolgáltatás nyújtására használt helyiség, továbbá a gyógyszertár, a gyógyászati segédeszközt forgalmazó üzlet és a dohánybolt kivételével az árusításra vagy szolgáltatás nyújtására használt, önkormányzati tulajdonban álló helyiség bérlóje a megkötött bérleti szerzôdésben meghatározott bérleti díj 50\%-át fizeti bérbeadónak 2020. április 1-jétôl 2020. augusztus 31-ig (illetve ha korábban megszúnik, a veszélyhelyzet kihirdetéséig).

A második intézkedési csomag 232020. április 30-án lépett hatályba az alábbi, lakásgazdálkodást is érintô rendelkezéssel: bármely jogcímen biztosított önkormányzati lakás (kivéve természetesen a korábban már szabályozott szociális lakás) bérlóje 2020. május 1. és augusztus 31. között (illetve a veszélyhelyzet megszúnéséig) a havonta fizetendô bérleti díj 50\%-át volt köteles fizetni bérleti díjként.

\section{ÖsszegzÉs}

A tanulmány bemutatta Győr város lakáspolitikáját az 1990-es évektôl kezdve a lakásgazdálkodás területén született helyi rendeletek, közgyúlési határozatok, illetve a Polgármesteri Hivatal Humánszolgáltatási Fóosztálya által szolgáltatott statisztikai adatok segítségével. Ahogy a humánszolgáltatások keretében ellátott többi feladatnál, helyi közszolgáltatásnál, úgy a lakásgazdálkodás területén is a kezdetektôl számos jó gyakorlat figyelhetố meg Gyôr városában. Fontos megjegyezni, hogy e területen Gyôrben nem csupán a klasszikus értelemben vett szociális bérlakásokról beszélhetünk, hanem végig prioritásként jelenik meg az önkormányzat lakáspolitikájában a szépko- rú generáció lakhatási problémáinak kezelése, illetve a fiatalok, családok lakáshoz jutásának támogatása is, a szociálisan rászorulók támogatása, segítése mellett. Az elôtakarékossággal meghirdetett lakáspályázat és a bérlakás felújítására meghirdetett pályázat nagyon népszerú lehetôségnek bizonyultak az elmúlt években, elsôsorban azért, mert a rendeleti feltételek között itt nem szerepel jövedelemhatár, így jóval szélesebb a pályázók köre. Szintén jó gyơri gyakorlatként azonosítható a kamatmentes önkormányzati kölcsön, mely támogatás szintén jó lehetôséget biztosít a Gyôrben való letelepedésre a szociálisan nem rászoruló, lakhatásukat majdnem önállóan megoldani tudó kérelmezôknek. A tanulmány a gyôri lakásügyi politika egy szegmensét vizsgálta csupán, további elemek vizsgálata késôbbi tudományos kutatások tárgyát képezi.

\section{JEGYZETEK}

1 A lakások és helyiségek bérletére, valamint az elidegenítésükre vonatkozó egyes szabályokról szóló 1993. évi LXXVIII. törvény.

2 1990. évi LXV. törvény a helyi önkormányzatokról.

3 1991. évi XXXIII. törvény egyes állami tulajdonban lévố vagyontárgyak önkormányzatok tulajdonába adásáról.

4 297/1995. (XI. 30.) GYŐR MJV Kgy. sz. határozat. 5 297/1995. (XI. 30.) GYŐR MJV Kgy. sz. határozat.

6 96/1996. (IV. 11.) GYỐR MJV Kgy. sz. határozat. 7 33/1999. (II. 11.) GYÔR MJV Kgy. sz. határozat. 238/1997. (VII. 3.) GYÔR MJV Kgy. sz. határozat. 9 196/1998. (VI. 11.) GYŐR MJV Kgy. sz. határozat. 10 33/1999. (II. 11.) GYÔR MJV Kgy. sz. határozat. 11 84/1997. (III. 20.) GYÔR MJV Kgy. sz. határozat.

12 A lakások és helyiségek bérletére, valamint az elidegenítésükre vonatkozó egyes szabályokról szóló 1993. évi LXXVIII. törvény 62. §.

13 481/2004. (XI. 25.) GYÔR MJV Kgy. sz. határozat.

14 202/2007. (VII. 05.) GYÔR MJV Kgy. sz. határozat.

15 42/2007. (XII. 21.) GYMJVÖ. rendelet az önkormányzati tulajdonú lakások és helyiségek elidegenítésérôl.

16 Magyarország helyi önkormányzatairól szóló 2011. évi CLXXXIX. törvény 3. § 9. pont.

17 Gyốr Megyei Jogú Város Önkormányzatának Szervezeti és Múködési Szabályzatáról szóló 


\section{Tudományos múhely}

30/2012. (XII. 19.) önkormányzati rendelet (5. melléklet).

18 30/2018. (XII. 20.) GYMJVÖ. rendelet - az önkormányzati tulajdonú lakások bérletérôl, valamint a lakásvásárlás és -építés támogatásáról.

19 30/2018. (XII. 20.) GYMJVÖ. rendelet.

20 Gyôr Megyei Jogú Város Polgármesteri Hivatal, Humánszolgáltatási Fốosztály adatszolgáltatása alapján.

21 2011. évi CXXVIII. törvény a katasztrófavédelemrôl és a hozzá kapcsolódó egyes törvények módosításáról.

22 7/2020. (IV. 1.) GYMJVÖ. rendelet egyes önkormányzati rendeleteknek a humánjárvány gazdasági következményeinek kezelése érdekében szükséges módosításáról.

23 15/2020. (IV. 30.) GYMJVÖ. rendelet az önkormányzati tulajdonú bérlakások veszélyhelyzetre tekintettel meghatározott bérleti díjáról.

\section{FeLHASZnÁlt IRODALOM}

Budai István (2014): Az együttmúködés mint a szociális szolgáltatásokban folyó tevékenység egyik építôköve. In: Csizmadia Zoltán - Tóth Péter (szerk.): Helyi társadalom és intézményrendszer Gyôrben. Universitas-Gyôr Nonprofit Kft., Gyôr, 230-244.

Budai István - Puli Edit (2014): Az együttmúködés vizsgálata a szociális szolgáltatásokban. Az altéma-kutatás eredményeinek összegzése. In: Csizmadia Zoltán - Tóth Péter (szerk.): Helyi társadalom és intézményrendszer Gyôrben. Universitas-Gyôr Nonprofit Kft., Gyôr, 272-290.

Bugovics Zoltán (2014): A gyôri identitás háttértényezôinek vizsgálata In: Csizmadia Zoltán - Tóth Péter (szerk.): Helyi társadalom és intézményrendszer Györben. Universitas-Gyôr Nonprofit Kft., Gyôr, 100-115.

Czakó Katalin - Hajdu-Smahó Melinda (2014): Vállalati nyitottság vizsgálata a Gyôri Jármúipari Körzet területi tôkéjében. In: Lados Mihály (szerk.): A gazdaságszerkezet és vonzáskörzet alakulása. Universitas-Gyôr Nonprofit Kft., Gyôr, 216-229.

Czirfusz Márton - Pósfai Zsuzsanna (2015): Kritikus ponton? Önkormányzati lakásgazdálkodás a gazdasági világválság után. Területi Statisztika, 55 . évf., 5. sz., 484-504.

Csizmadia Zoltán (2014a): A szociális intézményrendszer szereplőinek hálózati struktúrája. In:
Csizmadia Zoltán - Tóth Péter (szerk.): Helyi társadalom és intézményrendszer Gyốrben. Universitas-Gyôr Nonprofit Kft., Gyốr, 245-271.

Csizmadia Zoltán (2014b): A társadalmi kapcsolatok jellemzôi. A lakosság kapcsolati tôkekészletének sajátosságai. In: Csizmadia Zoltán - Tóth Péter (szerk.): Helyi társadalom és intézményrendszer Gyôrben. Universitas-Gyôr Nonprofit Kft., Gyôr, 129-153.

Dusek Tamás (2014): A közszolgáltatások területi és szervezeti hatékonysága és győri integrációja. In: Dusek Tamás (szerk.): A városi rendszer múködése. Közösségi szféra, oktatás és Gyốr jövôképe. Universitas-Gyôr Nonprofit Kft., Győr, 45-54.

Farkas E. János - Szabó Márta (1995): Privatizáció és szociálislakás-gazdálkodás. Statisztikai Szemle, 73. évf., 12. sz., 999-1014.

Fekete, Dávid (2018a): Economic Development and Economic Governance Through the Example of the City of Gyôr. Deturope, Vol. 10, No. 1, 97-115.

Fekete, Dávid (2018b): Latest Results of the Gyôr Cooperation Model. Polgári Szemle/Civic Review, Vol. 14, Special Issue, 195-209, https://doi. org/10.24307/psz.2019.0915.

Fekete Dávid (2018c): Gyốri fejlesztések a Modern Városok Program keretében. Területi Statisztika, 58. évf., 6. sz., 638-658, https://doi. org/10.15196/ts580605.

Fekete Dávid (2019): A Modern városok program jelentôsége a hazai városfejlôdésben. Tér és Társadalom, 33. évf., 1. sz., 27-43, https://doi. org/10.17649/tet.33.1.3066.

Fekete, Dávid - Laczkovits-Takács, Tímea (2019a): The Effect of Social Rehabilitation on the Urban Segregations. Deturope, Vol. 11, No. 2, 143-168.

Fekete Dávid - Laczkovits-Takács Tímea (2019b): Gyôr-Újvárosi szociális városrehabilitációs program a gyốri humánszolgáltatási modell vonatkozásában. In: Fekete Dávid (szerk.): Városfejlődés és agrárinnováció a Kárpát-medencében. A Gróf Bethlen István Kutatóközpont évkönyve. Universitas-Gyôr Nonprofit Kft., Győr, 73-96.

Hegedûs József - Várhegyi Éva (1999): A lakásfinanszírozás válsága a kilencvenes években. Közgazdasági Szemle, 46. évf., 2. sz., 101-120.

Kovács Lajos (2000): Lakáshelyzet Gyôrött. Jegyzô és Közigazgatás, 2. évf., 4. sz.

Kovács Zoltán (1992): Budapesti bérlakásszektor privatizációjának társadalmi és városszerkezeti hatásai. Tér és Társadalom, 6. évf., 3-4. sz., 55-73. 


\section{Tudományos múhely}

Laczkovits-Takács Tímea (2018a): Gyốr humánszolgáltatási modelljének egészségügyi pillére 1990-tôl napjainkig. Polgári Szemle, 14. évf., 1-3. sz., 90-106, https://doi.org/10.24307/ psz.2018.0808.

Laczkovits-Takács Tímea (2018b): Vázlat a Gyôri Egészséges Városok Program idősügyi intézkedéseirôl. In: Fekete Dávid - Filep Bálint (szerk.): Innováció, kultúra és életminôség a Kárpát-medence nagyvárosaiban. Az I. Gróf Bethlen István Erdélyi Nyári Egyetem válogatott tanulmányai. Universitas-Gyốr Nonprofit Kft., Gyốr, 53-64.

Laczkovits-Takács Tímea (2019a): Győr város önkormányzatának szerepvállalása a helyi szociális közszolgáltatások biztosításában. Tér-Gazdaság-Ember, 7. évf., 2-3. sz., 277-309.

Laczkovits-Takács Tímea (2019b): Idôsügy a gyôri Egészséges Városok Program tükrében. Polgári Szemle, 15. évf., 1-3. sz., 238-254, https://doi. org/10.24307/psz.2019.0915.

Laczkovits-Takács Tímea (2019c): Gyốr stratégiai dokumentumai a szociálpolitika tükrében. Szociálpolitikai Szemle, 5. évf., 1. sz., 81-95.

Laczkovits-Takács Tímea (2019d): Társadalmi részvétel és önkéntesség a gyôri Egészséges Városok Program keretein belül. In: Reisinger Adrienn et al. (szerk.): Kulturális Gazdaság. Kautz Gyula Emlékkonferencia, konferenciakötet, Széchenyi Egyetem, Gyôr.

Nárai Márta (1998): Bérlakásokkal vagy nélkülük? Lehetôségek és igények felmérése Gyôrött. Tér és Társadalom, 12. évf., 4. sz., 117-131.

Nárai Márta (2014a): Humán szükségletek alakulása Gyốrben I. - Alapszükségletek. In: Csizmadia Zoltán - Tóth Péter (szerk.): Helyi társadalom és intézményrendszer Gyôrben. Universitas-Gyôr Nonprofit Kft., Győr, 154-181.

Nárai Márta (2014b): Humán szükségletek alakulása Gyốrben II. - Magasabb rendú aktivitási szükség- letek. In: Csizmadia Zoltán - Tóth Péter (szerk.): Helyi társadalom és intézményrendszer Gyôrben. Universitas-Gyốr Nonprofit Kft., Gyôr, 182-200.

Páthy Ádám (2014): A társadalmi szerkezet belsố területi sajátosságai. In: Csizmadia Zoltán - Tóth Péter (szerk.): Helyi társadalom és intézményrendszer Györben. Universitas-Győr Nonprofit Kft., Gyôr, 48-74.

Rechnitzer János (2014): A gyốri gazdaság pályapontjai a rendszerváltástól napjainkig. In: Lados Mihály (szerk.): A gazdaságszerkezet és vonzáskörzet alakulása. Universitas-Gyôr Nonprofit Kft., Gyôr, 104-129.

Rechnitzer János (2016): A területi tốke a városfejlôdésben. A Gyôr-kód. Dialóg Campus Kiadó, Budapest-Pécs.

Reisinger Adrienn (2014a): Társadalmi részvétel - ahogy a gyôriek látják In: Csizmadia Zoltán Tóth Péter (szerk.): Helyi társadalom és intézményrendszer Gyôrben. Universitas-Gyôr Nonprofit Kft., Győr, 116-128.

Reisinger Adrienn (2014b): Vállalatok kapcsolati hálója Gyôrben és térségében. In: Lados Mihály (szerk.): A gazdaságszerkezet és vonzáskörzet alakulása. Universitas-Gyôr Nonprofit Kft., Gyôr, 230-243.

Róbert Péter (2014): Társadalmi rétegzôdés és mobilitás. In: Csizmadia Zoltán - Tóth Péter (szerk.): Helyi társadalom és intézményrendszer Gyôrben. Universitas-Gyôr Nonprofit Kft., Győr, 28-47.

Tóth Péter - Ditrói Zoltán (2014): A helyi társadalom dimenziói. In: Csizmadia Zoltán - Tóth Péter (szerk.): Helyi társadalom és intézményrendszer Gyôrben. Universitas-Gyôr Nonprofit Kft., Gyôr, 75-99.

Vígvári András (2008): Szubszidiaritás nélküli decentralizáció. Néhány adalék az önkormányzati rendszer magyar modelljének korszerúsítéséhez. Tér és Társadalom, 22. évf., 1. sz., 141-167. 